\title{
Identification of Resistance to Peppery Leaf Spot among Brassica juncea and Brassica rapa Plant Introductions
}

\author{
W. Patrick Wechter ${ }^{1}$ and Mark W. Farnham \\ United States Vegetable Laboratory, USDA-ARS, 2700 Savannah Highway, \\ Charleston, SC 29414
}

\section{J. Powell Smith}

Clemson University Cooperative Extension Service, Lexington County, 605 W. Main St., Ste. 109, Lexington, SC 29072

Anthony P. Keinath

Clemson University, Coastal Research and Education Center, 2700 Savannah Highway, Charleston, SC 29414

Additional index words. Brassica oleracea, Pseudomonas syringae pv. maculicola, bacterial leaf spot, vegetable Brassica, Brassica leafy greens

\begin{abstract}
Brassica leafy greens (Brassica juncea $\mathrm{L}$. and Brassica rapa $\mathrm{L}$.) represent one of the most economically important vegetable crop groups in the southeastern United States. In the last 10 years, numerous occurrences of a leaf-spot disease on these leafy vegetables have been reported in several states. This disease, known as peppery leaf spot, is now causing serious crop losses and has been attributed to the bacterial phytopathogen Pseudomonas syringae pv. maculicola (Psm). To date, it appears that all cultivars of the Brassica leafy greens are susceptible, and available pesticides for control of this disease appear unable to reduce the disease to acceptable levels. Thus, we undertook a search for potential resistance to this disease among accessions of $B$. juncea and $B$. rapa included in the U.S. Plant Introduction (PI) collection. In greenhouse trials, we screened commercial cultivars and 672 U.S. PIs (226 B. juncea and 446 B. rapa) for resistance to Psm with artificial inoculation. Although severity of disease symptoms was significantly different among inoculated accessions, no acceptable levels of resistance were found in any of the more than 400 B. rapa accessions tested. Only two B. juncea accessions (PI 195553 and $G$ 30988) of 226 tested had acceptable levels of resistance that might prove economically useful.
\end{abstract}

\begin{abstract}
"Brassica leafy greens" is a general term that includes several important vegetable crops, such as turnip greens (Brassica rapa L.), mustard greens (Brassica juncea L.), collards and kale (Brassica oleracea L. Acephala Group). More than $28 \mathrm{kt}$ of these greens are produced annually in the United States [U.S. Dept. of Agriculture (USDA), 2004]. In the United States, $\approx 70 \%$ of all commercial Brassica leafy greens are grown in Georgia, South Carolina, and Florida, putting these crops among the top vegetables of the Southeast. Because these vegetables are grown for the foliar portion of the plant, even slight deformity or blemishes of the leaves can result in consumer rejection and loss of product sales.
\end{abstract}

\footnotetext{
Received for publication 13 Dec. 2006. Accepted for publication $19 \mathrm{Feb} .2007$.

The contents of this publication do not necessarily reflect the views or policies of the USDA, nor does the mention of trade names, commercial products, or organizations imply endorsement by the United States Government.

The authors acknowledge the excellent technical assistance of Ms. Mary Curnen in this work.

${ }^{1}$ To whom reprint requests should be addressed; e-mail Pat.Wechter@ars.usda.gov
}

Several bacterial and fungal phytopathogens cause foliar diseases of Brassica. A number of the fungal foliar diseases (i.e., Alternaria or powdery mildew) can be effectively controlled using commercial fungicides (Ivors, 2006a, 2006b; Johnston, 2000; Maynard et al., 2003). Chemical control for most of the bacterial leaf-spot diseases of Brassica crops is limited; indeed, in the three management guides previously referenced above, Ivors (2006a, 2006b) and Maynard et al. (2003) make no mention of bacterial leaf-spot control measures, while Johnston (2000) gives only crop rotation away from Brassica spp. as a control measure for unspecified leaf spot.

Bacterial leaf spot, peppery leaf spot, or pepper spot, incited by Pseudomonas syringae pv. maculicola (Psm), is an example of a bacterial disease that is difficult to control in Brassica leafy greens. Psm was first reported on cauliflower (Brassica oleracea L. Botrytis Group) in the early 1900s (McCulloch, 1911). Bacterial leaf-spot disease incited by Psm has been documented in dozens of Brassica-growing regions throughout the world (Bradbury, 1986) and in several states, including California, Ohio, Oklahoma, South Carolina, and Tennessee (Campbell et al.,
1987; Cintas et al., 2002; Keinath et al., 2006; Koike, 2000; Lewis Ivey et al., 2001; Smith and Ramsey, 1953; Zhao et al., 2000b). Significant losses in Brassica leafy greens due to this disease have been reported in Oklahoma (Zhao et al., 2000b) and South Carolina (Keinath et al., 2006).

A few commercially available compounds are reported to reduce bacterial diseases of Brassica crops. For most of these products, the target pathogen is Xanthomonas campestris. Copper-based compounds, which are usually only partially effective against some bacterial phytopathogens, have not proven very effective in controlling Psm (Smith and Keinath, 2004; Zhao et al., 2000a). Recommended control strategies include rotating out of Brassica for 1-2 years, limiting overhead irrigation, and ensuring that seed is not infected (Smith and Keinath, 2004). In certain areas, growers are unable or unwilling to rotate out of these crops for extended periods. In addition, drip or furrow irrigation is not usually economical for this crop, and no reliable and sensitive method to detect this pathogen in seed stocks is currently available.

Previous research into identification of genes involved in disease resistance in Brassica has been successful. As an example, single dominant and recessive genes, as well as modifying genes have been found to confer varying levels of resistance to the downy mildew pathogen Peronospora (Hyaloperonospora) parasitica in broccoli (Dickson and Petzoldt, 1993; Hoser-Krauze et al., 1987; Natti et al., 1967). Studies on the downy mildew resistance genes $D m r 1$ (Farnham et al., 2002) and Dmr2 and Dmr3 (Wang et al., 2001) have led to development of resistant inbred broccoli lines. A number of studies have investigated the inheritance of resistance in Brassica to certain bacterial diseases, such as the black rot pathogen Xanthomonas campestris pv. campestris (Bain, 1952; Guo et al., 1991; Taylor et al., 2002; Vicente et al., 2002). Unfortunately, to date, there are no black rot resistant commercial cultivars available for the grower. In addition, we are unaware of any documented resistance to $P s m$ in commercial varieties of Brassica crops in general and leafy greens in particular. Our own observations of varieties grown in the southeastern United States are that slight differences in severity of Psminduced leaf spot occurs among cultivars, but in no case is resistance at an acceptable level for product marketability.

Mechanisms of disease resistance to Psm have been studied in depth by numerous researchers using the model plant Arabidopsis thaliana. Arabidopsis is a member of the Brassicaceae Family, and thus the information gained from this nonagricultural plant can be important in developing strategies to breed resistant vegetable Brassicas. Most of the Arabidopsis-based research studies use the phytopathogens $P s m$ or $P$. syringae pv. tomato DC3000. Gene-for-gene interactions involving bacterial avirulence proteins and the corresponding plant-resistance proteins 
(Martin et al., 2003) have been well documented in studies using both these phytopathogens (Alfano and Collmer, 2004; Pedley and Martin, 2003). Because Psm resistance has been identified in A. thaliana, this suggests that resistance to this pathogen is likely to be found in other genera of Brassicaceae. Thus, our objective in this study was to screen a collection of $B$. juncea and $B$. rapa germplasm for response to inoculation with Psm and to identify sources of resistance that might be incorporated into improved cultivars of these species.

\section{Materials and Methods}

Plant materials. B. juncea and B. rapa accessions (Plant Introductions) were obtained from the USDA, ARS, North Central Regional Plant Introduction Station (NCRPIS) in Ames, IA, and from the Northeast Regional Plant Introduction Station, USDA, ARS Plant Genetic Resources Unit (NRPIS) in Geneva, NY. One hundred seventy-five $B$. juncea and $302 B$. rapa accessions, designated as oilseed Brassicas from NCRPIS, were included in these tests. Fifty-one B. juncea and 144 B. rapa accessions, designated as vegetable Brassicas from NRPIS, were also included. The sample of oilseed accessions evaluated in this study is a subset of all available accessions held at NCRPIS and excludes redundancies recognized by the curator. The sample of vegetable accessions from NRPIS represents all available accessions held at this location. In addition to these accessions, a number of cultivars commonly grown in the southeastern United States were obtained from commercial sources.

Bacterial isolates. Bacterial isolates were collected from several commercial growing regions in South Carolina. Isolates were obtained by first surface-disinfesting dissected portions of infected leaves from commercially grown Brassica crops with a $0.5 \%$ sodium hypochlorite solution. The tissue was ground in phosphate-buffered saline (PBS), then spread plated onto Pseudomonas agar $\mathrm{F}$ (PAF). Following incubation at $27{ }^{\circ} \mathrm{C}$ for $48 \mathrm{~h}$, colonies that fluoresced blue under long-range ultraviolet light were selected. Identification of colonies as Psm was achieved using both molecular-based, as well as standard microbiological techniques (Keinath et al., 2006). All isolates were streaked to single colony a minimum of three times and stored in nutrient broth amended with $15 \%$ glycerol at $-80{ }^{\circ} \mathrm{C}$. Pathogenicity tests were performed on $B$. rapa Topper using a subset of these collected Psm isolates. One isolate, T3C, was found to be highly virulent and gave consistent disease symptoms in spray inoculation tests in the greenhouse (data not shown). T3C was used in all subsequent greenhouse inoculations.

Disease screens. Thirty to 35 accessions, as well as the susceptible commercial hybrid turnip Topper (as control), were screened in a single test and a series of 21 total tests were conducted to evaluate all 672 accessions.
Each test was run as a randomized complete block with two replications. Two blocks or reps of four plants each represented every accession in a given test, and each block of accessions was placed together on a greenhouse bench. Seed were sown in Metro-Mix 200 soil mix (The Scott's Co., Marysville, $\mathrm{OH})$ in $5 \mathrm{~cm} \times 5 \mathrm{~cm}$ pots. Plants were thinned to one plant per pot at $10 \mathrm{~d}$ after seeding, pots were arranged in open, self-draining trays. Metro-Mix 200 has a starter nutrient charge, and no additional fertilizer was applied during the tests. Psm inoculations were performed 3 weeks after seeding. All tests were conducted in a greenhouse with no supplemental lighting at Charleston, SC, from March through October, and temperatures typically ranged from 28 to $35^{\circ} \mathrm{C}$.

For inoculations, Psm T3C was grown on PAF medium for $16 \mathrm{~h}$ at $27{ }^{\circ} \mathrm{C}$. Cells were then harvested and resuspended in sterile distilled $\mathrm{H}_{2} \mathrm{O}\left(\mathrm{ds}_{2} \mathrm{O}\right)$. The cell suspension was adjusted to an optical density at $600 \mathrm{~nm}$ of 0.8 with $\mathrm{sdH}_{2} \mathrm{O}\left(\approx 1 \times 10^{7} \mathrm{CFU}\right.$ per $\mathrm{mL}$ of Psm cells, as determined by dilution plating). The surfactant Latron B-1956 (Dow Agrosciences LLC, Indianapolis) was added to the cell suspension at $3.2 \mu \mathrm{L} \cdot \mathrm{mL}^{-1}$ to enhance leaf coverage. The suspension was applied to the leaves using a Paashe model-H airbrush sprayer at $\approx 170 \mathrm{kPa}$ until the leaf surface was uniformly covered. Inoculated plants were placed in a humidity tent at $100 \%$ relative humidity for 16-24 $\mathrm{h}$ and then transferred to the greenhouse bench for $7 \mathrm{~d}$ before rating for disease.

The two most severely affected leaves from each plant were rated. A disease severity rating scale of 1-6 was used based on percentage of affected leaf tissue, $1=0 \%$ leaf area diseased; $2=1-10 \%$ diseased; $3=11$ $25 \%$ diseased; $4=26-50 \%$ diseased; $5=51-$ $75 \%$ diseased; $6=76-100 \%$ diseased. To normalize the data, each of the 1-6 ratings for each leaf was converted to an average percentage of disease with $1=0 \%, 2=5.5 \%, 3=$ $18 \%, 4=38 \%, 5=63 \%$, and $6=88 \%$. With each test, the above percentages were used to compute a single plant mean (within an accession) and also a block mean for a given accession (based on four plants per block).

Retest of primary selections. Accessions that exhibited a mean disease severity (MDS), determined by the average percent disease of all scored leaves of an accession, of $7 \%$ or less and that exhibited a severity rating significantly lower than the Topper control in preliminary analysis of variance were deemed to be putatively resistant and included in three additional greenhouse tests. A few additional accessions not deemed resistant were also included in retests because they exhibited other desired characteristics and moderate severity ratings.

Production of experimental plants in the retests was the same as described above. Each test was conducted as a randomized complete block, and the number of blocks was increased from two to four. The same inoculation procedures and disease ratings were conducted as before. Whereas disease ratings were only taken $7 \mathrm{~d}$ after inoculation in the initial tests to identify putative resistance, in two of the retests, ratings were taken 2, 4,7 , and $10 \mathrm{~d}$ postinoculation. As described above, these ratings were also converted to percentages and then used to compute area under the disease progress curve (AUDPC; Shaner and Finney, 1977).

Statistical analysis. Disease ratings were subjected to analysis of variance using a general linear models procedure of SAS version 9.1 (SAS Institute, Cary, NC). For the overall screen of 672 accessions, each individual set was analyzed separately with two replications. Data from follow-up experiments were analyzed separately initially. Because analysis indicated no significant differences among tests and homogeneity of error variances between retests, results were combined for overall analysis. Additionally, when ratings were taken at four different times postinoculation in retests, AUDPC was similarly analyzed as above.

\section{Results}

Of the 672 B. juncea and B. rapa accessions screened for resistance to the peppery leaf-spot pathogen Psm, the vast majority were found to be susceptible. Using the commercial turnip green cultivar Topper (B. rapa) as the susceptible control, most accessions tested were found to be as susceptible or more so than this cultivar (Tables 1 and 2 given as examples). The relative susceptibility of Topper varied from test to test in the initial screens, ranging from a low of $\approx 20 \%$ (Table 2 ) to a high of $\approx 40 \%$ (Table 1). Apart from this variation, each test of 30-35 accessions exhibited a wide range of disease scores among accessions, and significant differences within a test were common. Typically, percent infection ranged from $<10 \%$ to $\geq 50 \%$ (Tables 1 and 2).

Lines with MDS $\leq 7 \%$ and MDS significantly less than Topper were advanced to the secondary disease evaluations. Thus only four $B$. rapa accessions and six B. juncea accessions were advanced. In addition, a few accessions, including PI 508422 (B. rapa), PI 212594 (B. juncea), PI 30989 (B. juncea), and PI 209021 (B. juncea), were advanced based on a moderate level of resistance and interest by growers for other marketable qualities (data not shown).

The four putative resistant $B$. rapa accessions chosen for further screening were $G$ 30794 with MDS rating of $0.7 \%$, PI 418985 (MDS 4.0\%), PI 508419 (MDS $1.4 \%$ ), and G 30449 (MDS 2.5\%). All four of these $B$. rapa accessions identified in the first rounds of screening were also found to have significantly lower MDS than Topper in the secondary evaluations (Table 3). Although these accessions were determined to be more resistant to Psm than Topper, the level of resistance was much lower in the retests than originally observed and not adequate enough to be acceptable to the industry (Table 3 ). Thus, we did not verify 
Table 1. Mean disease severity (percent leaf area infected) for a representative set of $31 \mathrm{~B}$. rapa accessions and the susceptible control cultivar Topper following artificial inoculation with Psm.

\begin{tabular}{|c|c|}
\hline Accession & Disease severity $(\%)^{z}$ \\
\hline PI 478323 & $72.7 \mathrm{a}$ \\
\hline PI 518842 & $56.1 \mathrm{ab}$ \\
\hline PI 518844 & $47.7 \mathrm{bc}$ \\
\hline PI 489751 & $45.1 \mathrm{bcd}$ \\
\hline PI 508424 & $44.2 \mathrm{bcd}$ \\
\hline Topper & 40.8 bcde \\
\hline PI 508425 & 39.8 bcdef \\
\hline PI 436671 & 38.1 bcdefg \\
\hline PI 518843 & 37.5 bcdefgh \\
\hline PI 527322 & 36.9 bcdefgh \\
\hline PI 478345 & 36.8 bcdefgh \\
\hline PI 508417 & 35.7 cdefghi \\
\hline PI 508430 & 33.4 cdefghij \\
\hline PI 508409 & 30.9 cdefghij \\
\hline PI 508414 & 30.2 cdefghij \\
\hline PI 518841 & 30.0 cdefghij \\
\hline PI 478324 & 29.2 cdefghij \\
\hline PI 508421 & 25.9 defghijk \\
\hline PI 508428 & 25.4 efghijk \\
\hline PI 527323 & 23.5 efghijk \\
\hline PI 518840 & 23.2 efghijk \\
\hline PI 508415 & 22.5 efghijk \\
\hline PI 508422 & 21.8 efghijkl \\
\hline PI 478348 & 21.5 efghijkl \\
\hline PI 508423 & 20.2 fghijkl \\
\hline PI 508426 & 18.6 ghijkl \\
\hline PI 508408 & 18.2 ghijkl \\
\hline PI 518846 & 17.9 hijkl \\
\hline PI 436669 & $16.2 \mathrm{ijkl}$ \\
\hline PI 508418 & $13.8 \mathrm{jkl}$ \\
\hline PI 508427 & $8.5 \mathrm{kl}$ \\
\hline PI 508419 & 1.41 \\
\hline
\end{tabular}

${ }^{\mathrm{z}}$ Mean values followed by the same letter are not significantly $(P \leq 0.05)$ different from one another based on Fisher's protected LSD.

any suitable sources of resistance among the B. rapa accessions tested.

The six $B$. juncea chosen for further evaluation were PI 271455 with MDS $3.1 \%$, PI 432390 with MDS 6.2\%, PI 432377 with MDS $1.4 \%$, PI 418956 with MDS 3.8\%, G 30988 with MDS 7.0\%, and PI 195553 with MDS $1.5 \%$. As with B. rapa accessions chosen for retesting, all of the above $B$. juncea accessions were also found to be significantly more resistant than the susceptible Topper control on retesting (Table 3). The three best performers in the secondary evaluation were the $B$. juncea accessions PI 418965 with a MDS of $15.6 \%$, G 30988 with MDS $7.3 \%$, and PI 195553 with MDS $0.0 \%$ (Table 2). Using a cutoff of $\approx 7 \%$ disease or less, only two accessions from $246 \mathrm{~B}$. juncea tested were confirmed to be highly resistant. One of these, PI 195553, which appeared to be nearly immune to Psm, is an oilseed-type B. juncea, the other, G 30988, with a high level of resistance to Psm, is a vegetable-type B. juncea.

The variable AUDPC, calculated for all accessions in the retests, followed almost the exact same pattern among accessions as did percent disease severity measured $7 \mathrm{~d}$ postinoculation (Table 3). The correlation between the two variables was significant
Table 2. Mean disease severity (percent leaf area infected) for a representative set of $35 \mathrm{~B}$. juncea accessions and the susceptible control cultivar Topper following artificial inoculation with Psm.*

\begin{tabular}{|c|c|}
\hline Accession & Disease severity $(\%)^{z}$ \\
\hline PI 4251239 & $48.0 \mathrm{a}$ \\
\hline PI 212594 & $47.1 \mathrm{ab}$ \\
\hline PI 211000 & $46.0 \mathrm{abc}$ \\
\hline PI 212082 & $44.4 \mathrm{abcd}$ \\
\hline PI 346876 & 38.5 abcde \\
\hline PI 370745 & 36.1 abcdef \\
\hline PI 182921 & 35.5 abcdef \\
\hline PI 250131 & 35.2 abcdef \\
\hline PI 209781 & 35.0 abcdef \\
\hline PI 212970 & 34.6 abcdef \\
\hline PI 271442 & 34.3 abcdefg \\
\hline PI 288725 & 32.8 bcdefgh \\
\hline PI 288724 & 31.4 cdefghi \\
\hline PI 250139 & 31.3 cdefghi \\
\hline PI 249555 & 30.3 defghi \\
\hline PI 183117 & 28.8 efghi \\
\hline PI 250137 & 28.3 efghij \\
\hline PI 181043 & 28.0 efghijk \\
\hline PI 340213 & 27.1 efghijk \\
\hline PI 340220 & 26.8 efghijk \\
\hline PI 340206 & 25.0 efghijkl \\
\hline PI 347617 & 24.7 efghijkl \\
\hline PI 208734 & 23.9 efghijkl \\
\hline PI 254361 & 23.0 efghijkl \\
\hline Topper & 21.1 fghijkl \\
\hline PI 347615 & 19.4 ghijkl \\
\hline PI 340219 & 18.9 hijkl \\
\hline PI 358591 & 18.7 hijkl \\
\hline PI 340217 & $17.2 \mathrm{ijklo}$ \\
\hline PI 280637 & 13.7 jklop \\
\hline PI 209021 & 13.0 klop \\
\hline PI 387819 & 10.6 lop \\
\hline PI 257240 & 7.5 lop \\
\hline PI 286417 & 6.1 lop \\
\hline PI 271455 & 3.2 op \\
\hline PI 195553 & $1.5 \mathrm{p}$ \\
\hline
\end{tabular}

${ }^{\mathrm{z}}$ Mean values followed by the same letter are not significantly $(P \leq 0.05)$ different from one another based on Fisher's protected LSD.

$(P<0.0001)$ and very high $\left(r^{2}=0.991\right)$, indicating an extremely close relationship between them.

\section{Discussion}

Brassica leafy greens must have extremely low levels of imperfections at harvest to be acceptable to consumers. Slight marring of leaves that can result from disease lesions in conjunction with the likelihood that lesions can continue to develop postharvest can make infected leaves difficult to market. Thus, we set a rigorous standard to identify putative resistance requiring acceptable accessions to be significantly less susceptible than Topper and to exhibit very low disease levels. An important reason for the dual criteria was that we observed test-to-test variation in the response of Topper among the 21 tests that were conducted to evaluate all 672 accessions (Tables 1 and 2). This variation in Topper performance is likely attributable to environmental variation that resulted as a consequence of conducting the series of tests over an extended period of time in a greenhouse. In an ideal situation, it would be best to evaluate all materials at one time.
However, because of limited availability of space, we conducted a series of tests to evaluate this large collection of $B$. rapa and B. juncea.

Specific disease ratings for the total 672 accessions evaluated in this study were not all presented to simplify this presentation. Most accessions examined were susceptible and the exact response to inoculation with Psm is not pertinent. However, this research was partially funded by the USDA-ARS-National Plant Germplasm System to provide information about PIs held in the Brassica collections. The specific disease ratings are being given to the Brassica curators at Geneva, NY, and Ames, IA, and will be made available through the Germplasm Resource Information Network, which is accessible online (www.ars-grin.gov).

Only six $B$. juncea and four $B$. rapa accessions were identified as having putative resistance after all initial disease evaluations were completed. Following the secondary tests to confirm resistance, only two of the $B$. juncea accessions were shown to have the necessary low disease levels to be economically useful (Table 3). Of the two mostresistant accessions, PI 195553 appears to be nearly immune to Psm infection while G 30988 just meets the criteria we established for useful resistance. The remaining four $B$. juncea accessions and all four $B$. rapa accessions identified as putatively resistant did not appear as resistant after more thorough testing. Apparently, our initial evaluations were prone to identify some false positives. However, it is important to note that after all secondary evaluations, the eight putatively resistant accessions were all significantly less susceptible to Psm than Topper. We assume there must be some partial resistance operating in these latter accessions, but also that it is not adequate to protect leaves from unacceptable levels of damage.

An alternative way one might evaluate a large collection like that examined in this study would be to run a large field trial where the plots are artificially inoculated or where a natural infestation could be expected. For Psm this is problematic because we have recently determined that $P s m$ is often isolated from infested fields in combination with a leaf spotting Xanthomonas campestris pathovar and $X$. campestris pv. campestris (unpublished data). A similar, dual infection of leafy crucifers by PSm and a leaf-spotting $X$. campestris pathovar was reported by Zhao et al. (2000a) in Oklahoma. Due to these complications, we concluded that it was more logical to initially identify resistance in controlled environments rather than in field tests.

The two resistant $B$. juncea accessions identified in our trials come from very different sources. The resistant vegetable G 30988 is of Chinese origin and has the designated name Lian Cheng Green. This accession looks similar to some mustard greens and might be readily crossed to current cultivars to generate segregating populations of individuals with both peppery leafspot resistance and a desirable horticultural 
Table 3. Mean disease severity at 7 days postinoculation and area under the disease progress curve (AUDPC) of Brassica accessions selected for retesting for response to inoculation with Psm.

\begin{tabular}{lllcc}
\hline Accession & Species & \multicolumn{1}{c}{ Crop } & $\begin{array}{c}\text { Day 7 disease } \\
\text { severity }(\%)^{\mathrm{z}}\end{array}$ & AUDPC $^{\mathrm{z}}$ \\
\hline BLUE KNIGHT & B. oleracea & Kale & $55.2 \mathrm{a}$ & $329 \mathrm{a}$ \\
TOPPER & B. rapa & Turnip green & $54.4 \mathrm{a}$ & $336 \mathrm{a}$ \\
USVL108 & B. oleracea & Broccoli & $50.1 \mathrm{a}$ & $291 \mathrm{a}$ \\
HI CROP & B. oleracea & Collard & $38.5 \mathrm{~b}$ & $232 \mathrm{~b}$ \\
PI 271455 & B. juncea & Oilseed & $37.9 \mathrm{~b}$ & $224 \mathrm{~b}$ \\
PI 508422 & B. rapa & Vegetable & $36.8 \mathrm{~b}$ & $210 \mathrm{bc}$ \\
PI 212594 & B. juncea & Oilseed & $31.6 \mathrm{bc}$ & $181 \mathrm{bcd}$ \\
G 30989 & B. juncea & Vegetable & $31.4 \mathrm{bc}$ & $168 \mathrm{cde}$ \\
PI 30794 & B. rapa & Vegetable & $26.3 \mathrm{~cd}$ & $154 \mathrm{de}$ \\
PI 209021 & B. juncea & Oilseed & $25.4 \mathrm{cde}$ & $156 \mathrm{de}$ \\
PI 508419 & B. rapa & Vegetable & $24.8 \mathrm{cde}$ & $136 \mathrm{def}$ \\
PI 432390 & B. juncea & Oilseed & $22.6 \mathrm{cde}$ & $136 \mathrm{def}$ \\
PI 418985 & B. rapa & Vegetable & $22.3 \mathrm{cde}$ & $138 \mathrm{def}$ \\
G 30449 & B. rapa & Vegetable & $21.1 \mathrm{de}$ & $121 \mathrm{efg}$ \\
PI 432377 & B. juncea & Oilseed & $20.9 \mathrm{de}$ & $100 \mathrm{fg}$ \\
PI 418956 & B. juncea & Oilseed & $15.6 \mathrm{ef}$ & $81 \mathrm{gh}$ \\
G 30988 & B. juncea & Vegetable & $7.3 \mathrm{fg}$ & $35 \mathrm{hi}$ \\
PI 195553 & B. juncea & Oilseed & $0.0 \mathrm{~g}$ & $0 \mathrm{i}$ \\
\hline
\end{tabular}

${ }^{\mathrm{z}}$ Mean values followed by the same letter are not significantly $(P \leq 0.05)$ different from one another based on Fisher's protected LSD.

${ }^{y}$ Determined to have acceptable levels of resistance to Psm for further breeding work.

phenotype. The resistant oilseed PI 195553 originates from Ethiopia and has no other data associated with it. Although this line is nearly immune, it looks much less like a common turnip or mustard green. On the contrary, PI 195553 produces relatively few and small leaves and begins to flower after only $\approx 5-6$ weeks of growth. PI 195553 should readily cross with other $B$. juncea cultivars or accessions, but it will likely require a more concerted effort to move the resistance from this accession into an improved background.

We monitored disease severity over ten days in two retests to determine if the progress of disease infection (e.g., reflected by AUDPC) varied among accessions. The very close relationship between AUDPC and disease severity at day 7 (Table 3 ) indicates that disease progressed similarly among all lines and that the day 7 assessment of disease in this study adequately differentiated lines for resistance or relative susceptibility.

This research represents the first formal report of variable responses to $P_{S m}$ among a relatively large collection of accessions within a Brassica species. Other reports have described different responses to inoculation with Psm and other $P$. syringae pathovars among different Brassica species, but the focus of those studies was the differentiation of isolates and pathovars of leaf spotting P. syringae (Bull and Goldman, 2004; Cintas et al., 2002; Koike et al., 1998; Zhao et al., $2000 \mathrm{~b}$ ). This is the first report aimed at identifying resistant lines that might be used to breed improved crops with higher levels of resistance to Psm within a Brassica species. Our future efforts will be focused on using the potentially useful accessions found in this work to combat the damage incited by peppery leaf spot in leafy Brassica cultivars.

\section{Literature Cited}

Alfano, J.R. and A. Collmer. 2004. Type III secretion system effector proteins: double agents in bacterial disease and plant defense. Annu. Rev. Phytopathol. 42:385-414.

Bain, D.C. 1952. Reaction of Brassica seedlings to black rot. Phytopathology 42:497-500.

Bradbury, J.F. 1986. Guide to plant pathogenic bacteria. CAB International, Slough, U.K.

Bull, C.T. and P. Goldman. 2004. Bacterial blight on arugula, a new disease caused by Pseudomonas syringae pv. alisalensis in California. Plant Dis. 88:1384.

Campbell, R.N., P.J. Greathead, and S.T. Sim. 1987. Pepper spot of crucifers in California. Proc. Int. Conf. Plant Pathog. Bact. 6:668-671.

Cintas, N.A., S.T. Koike, and C.T. Bull. 2002. A new pathovar, Pseudomonas syringae pv. alisalensis pv. nov., proposed for the causal agent of bacterial blight of broccoli and broccoli raab. Plant Dis. 86:992-998.

Dickson, M.H. and R. Petzoldt. 1993. Plant age and isolate source affect expression of downy mildew in broccoli. HortScience 28:730 731.

Farnham, M.W., M. Wang, and C.E. Thomas. 2002. A single dominant gene for downy mildew resistance in broccoli. Euphytica 128:405-407.

Guo, H., M.H. Dickson, and J.E. Hunter. 1991. Brassica napus sources of resistance to black rot in crucifers and inheritance of resistance. HortScience 26:1545-1547.

Hoser-Krauze, J., E. Lakowska-Ryk, and J. Antosik. 1987. The inheritance of broccoli (Brassica oleracea L. var. botrytis) leaf resistance to downy mildew-Peronospora parasitica. (Pers.) ex Fr. Genet. Polon. 28:144-147.

Ivors, K. 2006a. Disease control for greens (collard, kale, mustard, rape), p. 174. In: D.C. Sanders (ed.). Vegetable crop handbook for the southeastern United States-2006. North Carolina Vegetable Growers Association, Raleigh.

Ivors, K. 2006b. Disease control for turnip, p. 200. In: D.C. Sanders (ed.). Vegetable crop handbook for the southeastern United States - 2006 North Carolina Vegetable Growers Association, Raleigh.

Johnston, S.A. 2000. Greens (mustard, turnip)disease control, p. 100. In: S.A. Garrison (ed.) Commercial vegetable production recommendations-New Jersey. Rutgers Coop. Ext. Serv., Rutgers State Univ. of New Jersey, New Brunswick.
Keinath, A.P., W.P. Wechter, and J.P. Smith. 2006. First report of bacterial leaf spot on leafy Brassica greens caused by Pseudomonas syringae pv. maculicola in South Carolina. Plant Dis. 90:683.

Koike, S.T. 2000. Bacterial blight, a new disease of broccoli caused by Pseudomonas syringae in California. Plant Dis. 84:370.

Koike, S.T., Henderson, D.H., Azad, H.R., and Cooksey, D.A. 1998. Bacterial blight of broccoli raab: a new disease caused by a pathovar of Pseudomonas syringae. Plant Dis. 82:727-731.

Lewis Ivey, M.L., S. Wright, and S.A. Miller. 2001. Report of bacterial leaf spot on collards and turnip leaves in Ohio. Plant Dis. 86:186.

Martin, G.B., A.J. Bogdanove, and G. Sessa. 2003. Understanding the functions of plant disease resistance proteins. Annu. Rev. Plant Biol. 54:23-61.

Maynard, D.N., G.J. Hochmuth, C.S. Vavrina, W.M. Stall, T.A. Kucharek, S.E. Webb, G.L. Leibee, T.G. Taylor, S.A. Smith, E.H. Simonne, and S.M. Olson. 2003. Cole crop production in Florida, p. 129-154. In: S.M. Olson and E. Simonne (eds.). Vegetable production handbook for Florida. Fla. Coop. Ext. Serv., Univ. Fla., Gainesville.

McCulloch, L. 1911. A spot disease of cauliflower. USDA, Bur. Plant Ind. Bull. 2251-15.

Natti, J.J., M.H. Dickinson, and J.D. Atkin. 1967. Resistance of Brassica oleracea varieties to downy mildew. Phytopathology 57:144-147.

Pedley, K.F. and G.B. Martin. 2003. Molecular basis of Pto-mediated resistance to bacterial speck disease in tomato. Annu. Rev. Phytopathol. 41:215-243.

Shaner, G. and R.E. Finney. 1977. The effect of nitrogen fertilization on the expression of slowmildewing resistance in Knox wheat. Phytopathology 67:1051-1056.

Smith, J.P. and A.P. Keinath. 2004. Crop profile for leafy greens and collards (fresh market) in South Carolina. National Information System for the Regional Integrated Pest Management Centers, North Carolina State University, Raleigh. <http://www.ipmcenters.org/croppro files/docs/scleafygreens.html>.

Smith, M.A. and G.B. Ramsey. 1953. Bacterial spot of broccoli. Phytopathology 43:583-584.

Taylor, J.D., J. Conway, S.J. Roberts, D. Astley, and J.G. Vicente. 2002. Sources and origin of resistance to Xanthomonas campestris pv. campestris in Brassica genomes. Phytopathology 92:105-111.

United States Department of Agriculture, National Agricultural Statistics Service. 2004. Vegetable summary. USDA/NAAS, Washington, D.C.

Vicente, J.G., J.D. Taylor, A.G. Sharpe, I.A.P Parkin, D.J. Lydiate, and G.J. King. 2002. Inheritance of race-specific resistance to Xanthomonas campestris pv. campestris in Brassica genomes. Phytopathology 92:1134 1141.

Wang, M., M.W. Farnham, and C.E. Thomas. 2001. Inheritance of true-leaf stage downy mildew resistance in broccoli. J. Amer. Soc. Hort. Sci. 126:727-729.

Zhao, Y.F., J.P. Damicone, D.H. Demezas, and C.L. Bender. 2000a. Bacterial leaf spot diseases of leafy crucifers in Oklahoma caused by Xanthomonas campestris. Plant Disease 84: 1008-1014.

Zhao, Y.F., J.P. Damicone, D.H. Demezas, V. Rangaswamy, and C.L. Bender. 2000b. Bacterial leaf spot of leafy crucifers in Oklahoma caused by Pseudomonas syringae pv. maculicola. Plant Dis 84:1015-1020. 